\title{
Gene variants of the renin angiotensin aldosterone system for risk stratification in heart disease
}

\author{
Barry R Palmer \\ School of Health Sciences, College of Health, Massey University, Wellington, New Zealand
}

\section{Related article}

by Gorący et al.

see p. 765

Correspondence to:
Barry R Palmer
School of Health Sciences,
College of Health, Massey
University, Wellington, New
Zealand,
phone: +6449793 463,
e-mail:
b.palmer@massey.ac.nz
Copyright by the
Author(s), 2021
Kardiol Pol. 2021;
79 (7-8): 728-729;
DOl: 10.33963/KP.a2021.0038
Received:
June 1, 2021
Revision accepted:
June 4, 2021
Published online:
June 7, 2021

Numerous studies on the potential of genetic variants of the renin-angiotensin-aldosterone system (RAAS) as markers of the development and progression of heart disease have been reported over the past three decades [1-3]. The RAAS has a central role in the control of blood pressure, is a major target for pharmacological control of hypertension, and its activity strongly influences many processes like thrombosis, apoptosis and smooth muscle cell proliferation that are major drivers of cardiovascular pathophysiology. Thus, making RAAS genes obvious candidates for the study of genetic causes of heart disease [4]. The genetics and physiology of a component of the RAAS, angiotensin converting enzyme 2 (ACE2), has also gained more importance recently, due to it being the cellular receptor for SARS-CoV-2 [5], the cause of the current COVID-19 pandemic, and other coronaviruses. The influence of $A C E 2$ gene variants on susceptibility to and/or on the severity of SARS-CoV-2 infection [6] and heart disease $[7,8]$ remains to be fully elucidated.

In the current issue Gorący et al. [9] describe a study of 401 patients with heart failure (HF) in which they examined the association of 3 common RAAS DNA polymorphisms: angiotensin-converting enzyme ( $A C E)$ ( $r$ 44646994), angiotensinogen (AGT) ( $r s 5051)$ and angiotensin II receptor type 1 (AGTR1) (rs5186) with HF pathology and left ventricular mass. In comparison with a control group of 120 volunteers without a history of heart disease, the study found a significant association between $\mathrm{HF}$ and $\mathrm{G}(-6) \mathrm{A} A G T$ genotype, the $\mathrm{AA}$ homozygotes of $A G T$ were significantly rarer in the HF group.
However no association with left ventricular mass was found with any of the 3 polymorphisms. The study highlights some of the challenges around the investigation of the genetic basis of cardiovascular disease.

Many studies, ranging from relatively small studies focused on candidate genes to large genome-wide association studies that objectively surveyed the entire genome, have found significant associations with a variety of genetic variants in numerous genes, some obvious candidate genes, and others with less obvious links to cardiovascular function revealed in genome-wide screens [10]. However the application of these findings to effective use in the diagnosis and treatment of heart disease is not well advanced. Despite it being 14 years since the landmark discovery that polymorphisms in the chromosome 9P21.3 region of the human genome were strongly associated with the development of coronary artery disease [11, 12], the use of this and other genetic markers as an aid to risk stratification is not widespread. Recent investigations of the utility of using genetic risk scores (GRS) for susceptibility to coronary disease have yielded results mostly supporting the discriminatory power of GRSs for risk stratification, with some exceptions that report little advantage over profiling using conventional risk factors [10]. The use of GRSs is also complicated by findings that the ethnicity and age of an individual may influence the choice of the most appropriate suite of gene variants to employ in an effective GRS [10]. Genetic risk stratification has the advantage over conventional risk scoring in that it can be carried out early in an individual's life. In con- 
trast, conventional risk factors usually reveal themselves later in life, often too late for effective primary prevention. However, when it is best to act on GRS data remains an open question.

The genetic analysis of the causes and trajectory of heart failure has made slower progress than that for other forms of heart disease like coronary artery disease or atrial fibrillation [13]. This is partly because heart failure may have a variety of causes, including chronic hypertension, valvular disease, ischaemic heart disease, infectious diseases, congenital heart diseases and hereditary cardiomyopathies, all of which reach a common endpoint pathology. While the genetics of heritable cardiomyopathies is relatively well characterised, many of which are due to mutations in genes encoding structural sarcomeric proteins [14], the same cannot be said for the more "common" forms of heart failure with diverse aetiologies.

In conclusion, the current situation with using genetic markers to aid in the diagnosis and management of heart disease shows there is much work to be done. Studies such as the one reported by Gorący et al. [9] are to be encouraged, and these, along with larger, high-powered, multi-centred studies focused on specific disease phenotypes, will help decode the complexity of the genetic basis of cardiovascular disease and inform how best to use genetic tools to prevent and treat these diseases.

\section{Article information}

Conflict of interest: None declared.

Open access: This article is available in open access under Creative Common Attribution-Non-Commercial-No Derivatives 4.0 International (CC BY-NC-ND 4.0) license, allowing to download articles and share them with others as long as they credit the authors and the publisher, but without permission to change them in any way or use them commercially. For commercial use, please contact the journal office at kardiologiapolska@ptkardio.pl.

How to cite: Palmer BR. Gene variants of the renin angiotensin aldosterone system for risk stratification in heart disease. Kardiol Pol. 2021; 79(7-8): 728-729, doi: 10.33963/KP.a2021.0038.

\section{REFERENCES}

1. Cambien $F$, Poirier $O$, Lecerf $L$, et al. Deletion polymorphism in the gene for angiotensin-converting enzyme is a potent risk factor for myocardial infarction. Nature. 1992; 359(6396): 641-644, doi: 10.1038/359641a0, indexed in Pubmed: 1328889.

2. Ellis KL, Palmer BR, Frampton CM, et al. Genetic variation in the renin-angiotensin-aldosterone system is associated with cardiovascular risk factors and early mortality in established coronary heart disease. J Hum Hypertens. 2013; 27(4): 237-244, doi: 10.1038/jhh.2012.24, indexed in Pubmed: 22739771.

3. Buraczyńska M, Pijanowski Z, Spasiewicz D, et al. Renin-angiotensin system gene polymorphisms: assessment of the risk of coronary heart disease. Kardiol Pol. 2003; 58(1): 1-9, indexed in Pubmed: 14502296.

4. Singh $M$, Singh $A K$, Pandey $P$, et al. Molecular genetics of essential hypertension. Clin Exp Hypertens. 2016; 38(3): 268-277, doi: 10.3109/10641963.2015.1116543, indexed in Pubmed: 27028574.

5. Qiu Y, Zhao YB, Wang Q, et al. Predicting the angiotensin converting enzyme 2 (ACE2) utilizing capability as the receptor of SARS-CoV-2. Microbes Infect. 2020; 22(4-5): 221-225, doi: 10.20944/preprints202003.0091.v1, indexed in Pubmed: 32199943.

6. Devaux CA, Rolain JM, Raoult D. ACE2 receptor polymorphism: susceptibility to SARS-CoV-2, hypertension, multi-organ failure, and COVID-19 disease outcome. J Microbiol Immunol Infect. 2020; 53(3): 425-435, doi: 10.1016/j.jmii.2020.04.015, indexed in Pubmed: 32414646.

7. Palmer BR, Jarvis MD, Pilbrow AP, et al. Angiotensin-converting enzyme 2 A1075G polymorphism is associated with survival in an acute coronary syndromes cohort. Am Heart J. 2008; 156(4): 752-758, doi: 10.1016/j. ahj.2008.06.013, indexed in Pubmed: 18926157.

8. Burrell LM, Harrap SB, Velkoska E, et al. The ACE2 gene: its potential as a functional candidate for cardiovascular disease. Clin Sci (Lond). 2013; 124(2): 65-76, doi: 10.1042/CS20120269, indexed in Pubmed: 23013041.

9. Gorący I, Peregud-Pogorzelska M, Safranow K, et al. Key genetic variants in the renin-angiotensin system and left ventricular mass in a cohort of Polish patients with heart failure. Kardiol Pol. 2021; 79(7-8): 765-772, doi: 10.33963/KP.15989, indexed in Pubmed: 33926172.

10. Roberts R, Chang CC, Hadley T. Genetic risk stratification: a paradigm shift in prevention of coronary artery disease. JACC Basic Transl Sci. 2021; 6(3): 287-304, doi: 10.1016/j.jacbts.2020.09.004, indexed in Pubmed: 33778213.

11. Samani NJ, Erdmann J, Hall AS, et al. WTCCC and the Cardiogenics Consortium. Genomewide association analysis of coronary artery disease. $\mathrm{N}$ Engl J Med. 2007; 357(5):443-453, doi: 10.1056/NEJMoa072366, indexed in Pubmed: 17634449.

12. McPherson R, Pertsemlidis A, Kavaslar N, et al. A common allele on chromosome 9 associated with coronary heart disease. Science. 2007; 316(5830): 1488-1491, doi: 10.1126/science.1142447, indexed in Pubmed: 17478681.

13. Miyazawa K, Ito K. The evolving story in the genetic analysis for heart failure. Front Cardiovasc Med. 2021; 8: 646816, doi: 10.3389/fcvm.2021.646816, indexed in Pubmed: 33928132

14. Martinez HR, Beasley GS, Miller N, et al. Clinical insights into heritable cardiomyopathies. Front Genet. 2021; 12: 663450, doi: 10.3389/fgene.2021.663450, indexed in Pubmed: 33995492. 